\title{
MACHINE TOOL LOADS IN ROTARY ULTRASONIC MACHINING OF Alumina, CBN AND SYNTHETIC DiAMOND
}

\author{
Kuruc Marcel \\ Slovak University of Technology in Bratislava, Faculty of Materials Science and Technology in Trnava, Institute of \\ Production Technologies, Department of Machining, Forming and Assembly, Jána Bottu 25, 91724 Trnava, \\ Slovak Republic
}

\begin{abstract}
Cubic boron nitride (CBN) and synthetic diamond (SD) belong to the hardest materials known. Materials of such hardness cannot be machined by conventional machining technologies. Therefore, advanced machining methods were designed. Advanced method of rotary ultrasonic machining (RUM) is especially suitable for machining the hard and brittle materials such as glass and ceramics. RUM is based on the abrasive removing mechanism of an ultrasonic vibrating tool with diamond particles on active part. The current contribution investigates machining of CBN and SD by the above-mentioned advanced machining method. Different types of machine tool loads are evaluated. The results are compared with the machine loads obtained in the machining of alumina ceramics, which is considered as one of the hardest ceramic materials. It is machined also by RUM. This is one of the first papers dealing with machine loads in the processing of ultra-hard materials.
\end{abstract}

Keywords: Rotary ultrasonic machining; Cubic boron nitride; Synthetic diamond; Alumina ceramic; Machine tool loads; Advanced machining
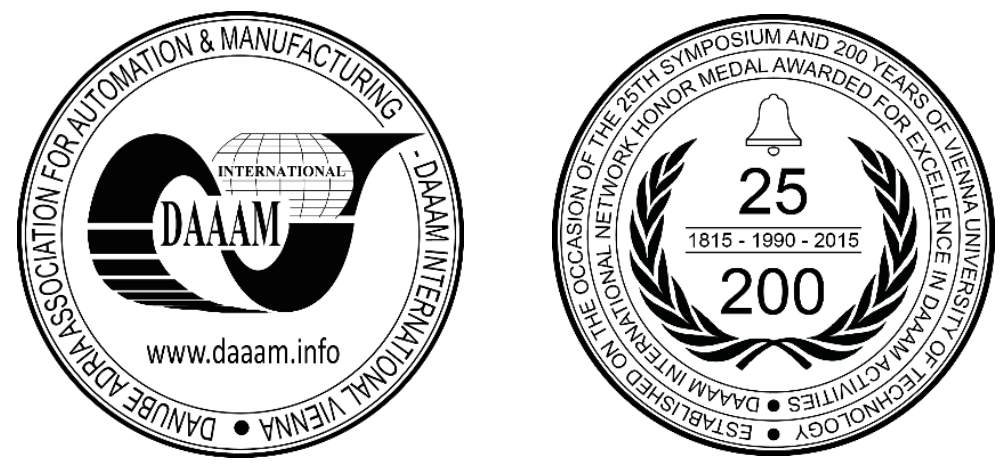

This Publication has to be referred as: Kuruc, M[arcel] (2016). Machine Tool Loads in Rotary Ultrasonic Machining of Alumina, CBN and Synthetic Diamond, Proceedings of the 26th DAAAM International Symposium, pp.0519-0523, B. Katalinic (Ed.), Published by DAAAM International, ISBN 978-3-902734-07-5, ISSN 1726-9679, Vienna, Austria DOI: $10.2507 / 26$ th.daaam.proceedings.070 


\section{Introduction}

CBN as well as SD are very hard materials which are manufactured under similar conditions - by powder metallurgy at $1500{ }^{\circ} \mathrm{C}$ and $5 \mathrm{GPa}$. Due to their hardness, any additional treatment is usually not necessary - it is often manufactured directly to the final shape (such as diamond tips for hardness measuring devices). However, there are some applications, where machining of very hard materials is demanded. An example of this application could be the tools for friction stir welding (FSW). FSW process is based on the application of a tool with specially designed shoulder and pin (Fig. 1 a), which is rotating and impressed to the interface of welded materials. During the welding process, majority of mechanical power is transferred to heat [1, 2, 3, 4 and 5]. Welding tool, which is utilized in FSW process, has to be sufficiently tough, robust and wear resistant, even at welding temperature. If not, it could be fatally damaged (Fig. $1 \mathrm{~b}$ ). Therefore, it has to be made of advanced materials, such as CBN, when the welding of stronger materials (such as the titanium and nickel alloys) is required. Such task can be performed only by using advanced machining methods. Therefore, there is a growing interest in the development and research of such methods and their applications. Ultrasonic machining is one of them.

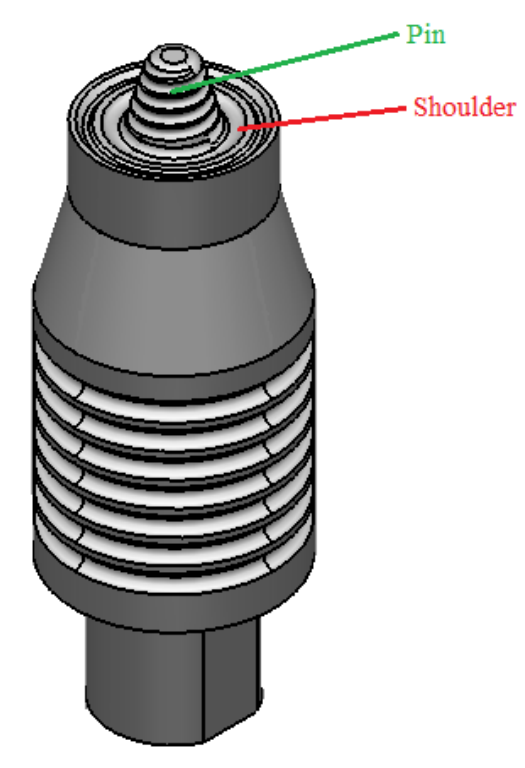

a)

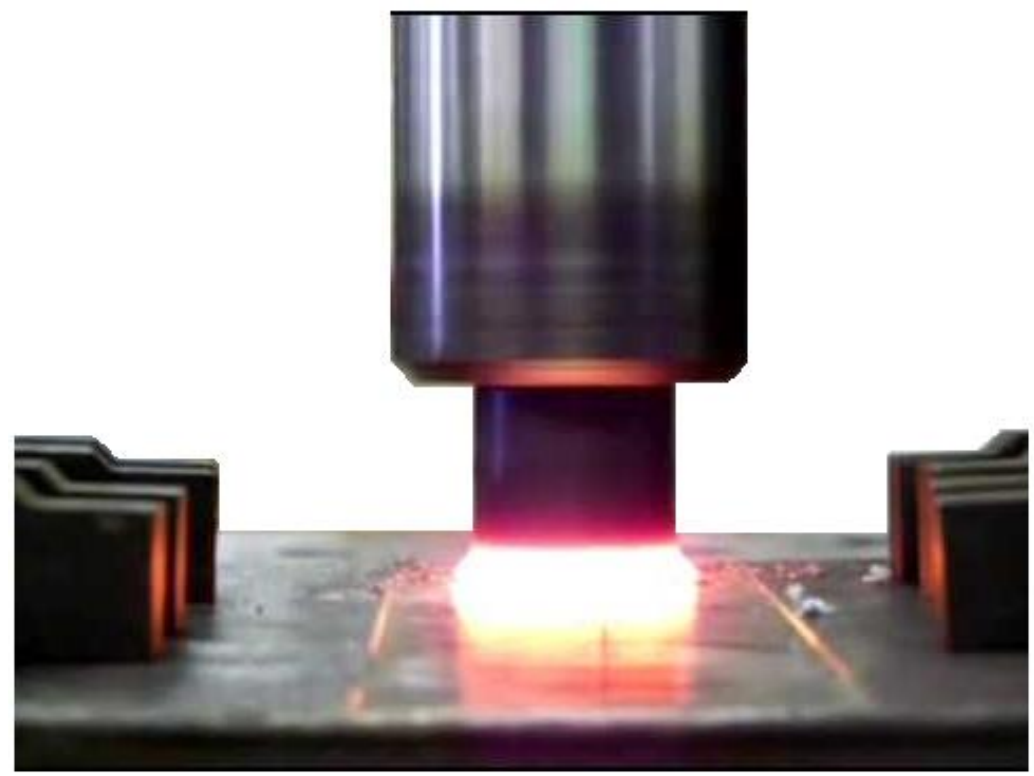

b)

Fig. 1. Tool for friction stir welding with a special design (a) and its improper usage (b) [6]

Ultrasonic machining is a relatively new machining method. Its authors have successfully applied ultrasonic assistance to improve the milling process [7 and 8], or observe the effect of ultrasound on the surface topography [9, 10 and 11]. This is one of the first papers dealing with machine loads at the processing of ultra-hard materials. However, the obtained results could be implemented in adjusting the most proper machining parameters for machining of very hard materials.

\section{Machining method}

In experiments, rotary ultrasonic machining (RUM) is applied. RUM utilizes a tool with diamond particles, which rotates around the vertical axis and oscillates at ultrasonic frequency in vertical direction. Rotating motion and vibration interaction cause micro-cracks on the surface. These cracks are chipped off and drained away as microchips by coolant. Coolant also enhances this effect by cavitation. Therefore, suitable properties of the coolant are necessary. Coolant is fed on the tool-workpiece interface. Accordingly, very hard and brittle materials (such as ceramics) can be machined. Advantages of this process are: decreased cutting force, reduced heat generation, no chemical affection of the workpiece, increased tool life, improved the surface machined, etc. In this experiment, DMG ULTRASONIC 20 linear rotary ultrasonic milling machine was used. This machine tool is able to operate continuously in five axes (X, Y, Z, A, C) [12, 13 and 14].

As a tool, ultrasonic milling cutter (Fig. 2) with diameter $24 \mathrm{~mm}$ was used. 3D model of the workpiece was created by PowerShape CAD software, and NC program for machining was generated by PowerMill CAM software [15 and 16]. 


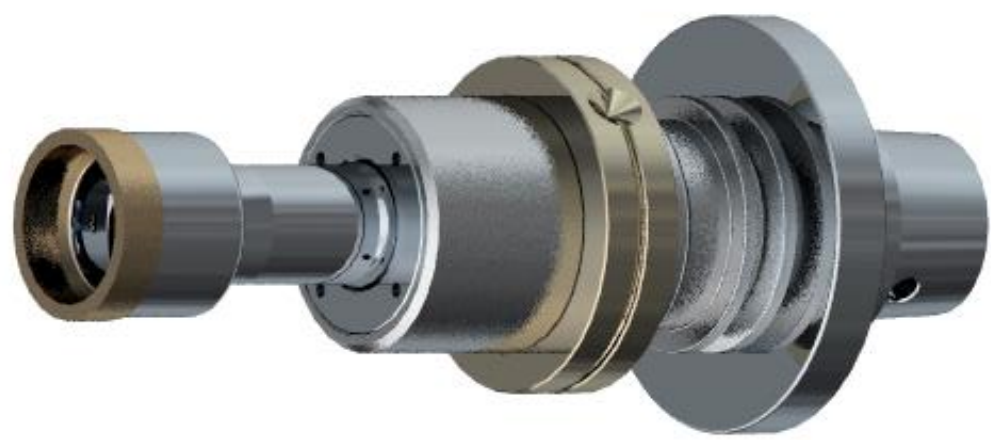

Fig. 2. Ultrasonic milling cutter with diamond abrasive

\section{Description of the experiment}

Alumina ceramics, cubic boron nitride (CBN) and synthetic diamond (SD) were used as the machined material, a. CBN has a polycrystalline structure and SD has a monocrystalline structure. Alumina ceramics was produced by Brisk the Czech Company, and CBN and SD were produced by 3B Diamonds Company in China. Estimated hardness of these materials is $2500 \mathrm{HV}, 4200 \mathrm{HV}$ and 10,000 HV respectively [17, 18 and 19].

For the experiments, we used: Alumina block with dimensions 100 x 100 x $25 \mathrm{~mm}, \mathrm{CBN}$ cylinder with diameter $30 \mathrm{~mm}$ and length $20 \mathrm{~mm}$, and SD block with dimensions $5 \times 4.5 \times 1 \mathrm{~mm}$. Specimens were machined under the same conditions. Clamping of specimens is shown in Fig. 3.
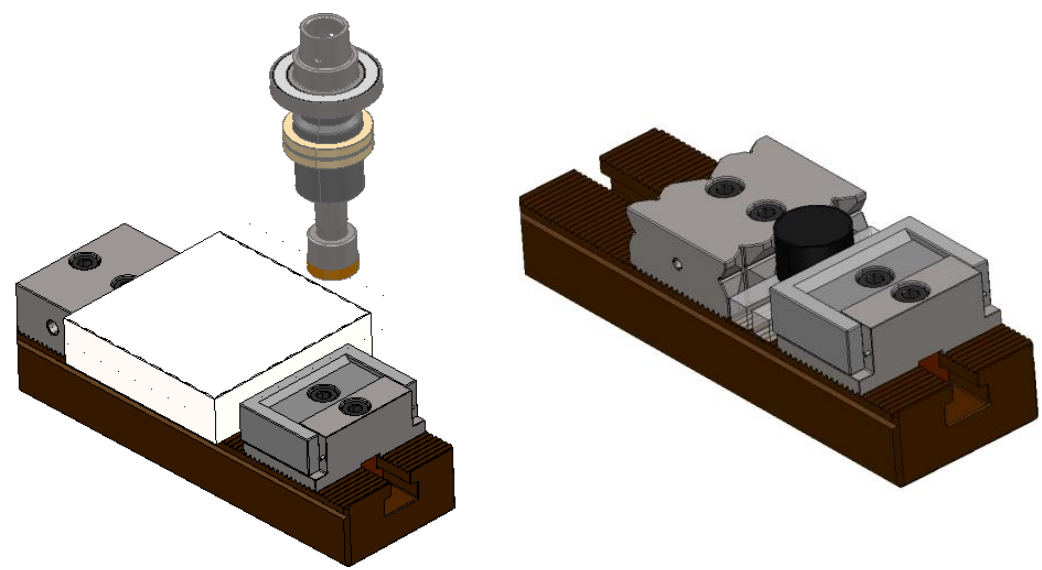

Fig. 3. Samples fixed in vice of machine tool

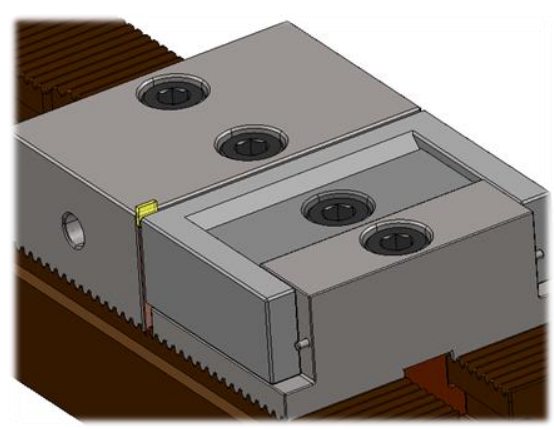

In experiments, we were changing: spindle speed 4000, 6000 and $8000 \mathrm{rpm}$ (corresponding to the cutting speed 300,450 and $600 \mathrm{~m} / \mathrm{min}$ ), feed rate 100,300 and $500 \mathrm{~mm} \cdot \mathrm{min}^{-1}$, and depth of cut 1, 3 and $5 \mu \mathrm{m}$. Constant features were: frequency of vibration $21.6 \mathrm{kHz}$ and amplitude of vibration $10 \mu \mathrm{m}$, as well as coolant concentration and its flow. The machine tool loads were evaluated directly on the machine tool. The loads in $\mathrm{X}$ axis, $\mathrm{Y}$ axis, $\mathrm{Z}$ axis, $\mathrm{A}$ axis and $\mathrm{C}$ axis, spindle load, torque, and load of ultrasonic generator were observed. However, in this paper, only the most significant values were recorded.

Results were also analyzed in Minitab software. The experiment of type $3 \times 3^{3}$ was used, where the three factors (spindle speed, feed rate, and depth of cut) were examined at three levels (lower, middle, and upper value), and this was repeated for all three materials (alumina, CBN, and SD). Due to the space saving, only their average results were recorded in the form of graphs. This method was chosen as the most appropriate one for this task.

\section{Results of the experiment}

Eight types of machine load were obtained. Change of machining parameters did not have a significant influence on the loads in X, Y, A and C axes. The most limiting factors were $\mathrm{Z}$ axis load and torque. Due to the space saving, only the arithmetical average values of the observed parameters were calculated. It means that point at spindle speed $4000 \mathrm{rpm}$ was created as the arithmetical value for this spindle speed at all feed rates and all depths of cut. Results of the experiments are summarized in Fig. 4 for torque and in Fig. 5 for $\mathrm{Z}$ axis load. Significant influence of machining parameters on $\mathrm{Z}$ axis load was not observed at machining of alumina ceramics (its value always was approx. $0 \%$ ). 


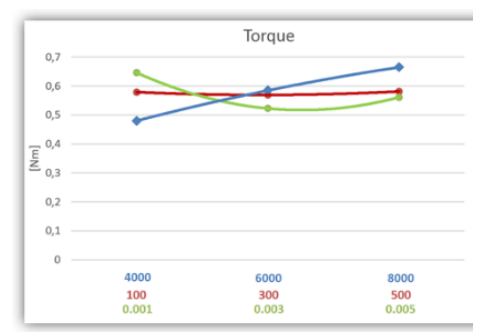

a)

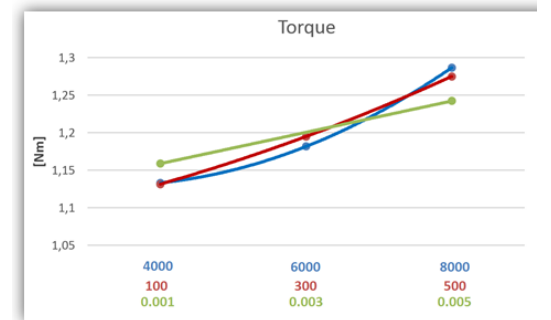

b)

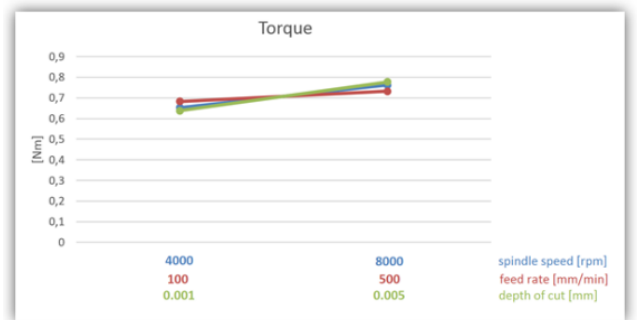

c)

Fig. 4. Influence of torque on machining parameters in the machining of (a) alumina ceramic, (b) CBN, and (c) SD
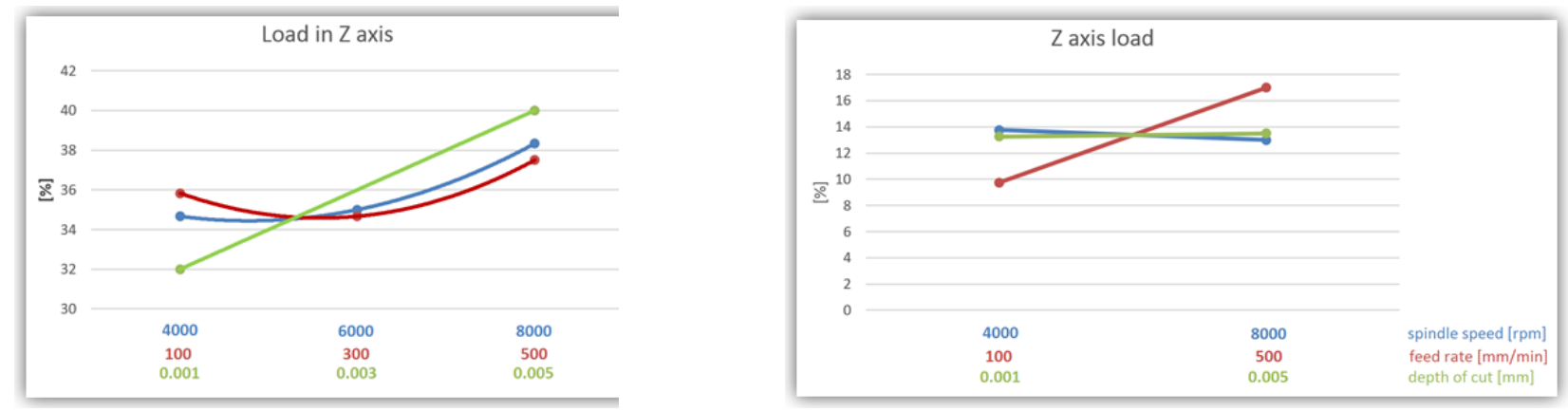

Fig. 5. Influence of $Z$ axis load on machining parameters in the machining of (a) CBN and (b) SD

During machining CBN, a "sticking effect" was observed. It is characterized by sticking of the workpiece material on the cutting tool. It negatively affects the whole machining process. Therefore, during machining CBN, higher values of torque as well as $\mathrm{Z}$ axis load were achieved in comparison with the machining of diamond.

In further experiments, we plan to examine the above-mentioned sticking effect phenomena and evaluate the tool wear in the rotary ultrasonic machining of these materials.

\section{Conclusion}

Rotary ultrasonic machining is able to machine very hard materials, such as CBN and synthetic diamond. Harder material causes higher machine tool load; however, it is affected also by the behaviour of machined material. The sticking effect of CBN negatively affects the machining process. Therefore, machine loads during machining of CBN are even greater when compared to the machining of harder diamond. The torque while machining the alumina ceramic is a bit lower than the torque in case of machining the $\mathrm{SD}$, however, it is approximately half the torque of that in machining the $\mathrm{CBN}$. Z axis load for CBN was twice as high as Z axis load for SD. Z axis load for alumina was not measurable at adjusted machining parameters. This sticking effect is caused probably by the presence of aluminum in matrix of PCBN. The amount of the workpiece material stuck to the tool will keep increasing with the total time of machining. To protect the tool, it is necessary to regularly clean it. Therefore, adjusting the lower cutting parameters should not really lead to the safer machining process in all cases. Sometimes, it is better to adjust higher cutting parameters (if machine tool allows it) and machine the CBN as fast as possible. Lower number of or breaks for cleaning means a lower chance to overload the cutting tool.

The results published in this paper could serve as a base for other research in this field. Moreover, it brings recommendations for adjusting proper machining parameters for machining the very hard materials to avoid overload of both cutting tool and machine tool. It can also prevent from dangerous sticking effect in the process of machining the $\mathrm{CBN}$. However, the results published in the paper are limited only to the very hard and brittle materials machined by the rotary ultrasonic machining.

Influence of a tool wear on the machining of the above-mentioned materials by RUM will be an objective of further research. Lower machine loads do not always mean the lower tool wear.

\section{Acknowledgements}

This contribution is a part of the GA VEGA project of Ministry of Education, Science, Research and Sport of the Slovak Republic, No. 1/0477/14 "Research of influence of selected characteristics of machining process on achieved quality of machined surface and problem free assembly using high Technologies".

This contribution is also elaborated by the support of Operational Project Research and Development of Centre of Excellence of Five Axis Machining, ITMS 26220120013, co-financed by the European Funds for Regional Development. 
This contribution is elaborated by support

of Operational Project Research and Development

of Centre of Excellence of Five Axis Machining, ITMS 26220120013, co-financed

by European Founds for Regional Development.
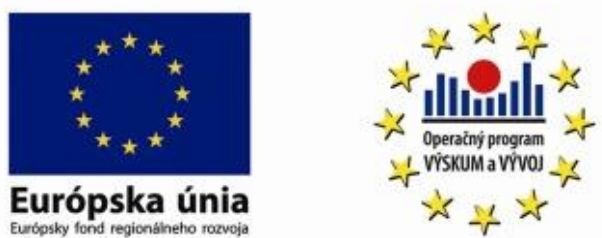

We are supporting of research activities in Slovakia/

Project is co-financed by sources of ES

\section{References}

[1] Friction Stir Welding. Technical Handbook. ESAB 2011.

[2] TWI - Friction Stir Welding. [online], [cit. 2014-03-01]. Available on the Internet: http://www.twi.co.uk/technologies/welding-coating-and-material-processing/friction-stir-welding/

[3] M. Turňa: Špeciálne metódy zvárania (Special welding methods). Bratislava: Alfa, 1989.

[4] Friction Stir Welding. [online], [cit. 2013-11-20]. Available on the Internet: http://med.iaun.ac.ir/site/files/iaun_staff_498.pdf

[5] I. Hrivňák: Zváranie a zvaritel'nost' materiálov (Welding and Weldability of Materials), Bratislava 2009 ISBN 978 80-227-3167-6.

[6] Friction Stir Welding (FSW) of Steel with a Steel Tool. [online], [cit. 2015-09-17]. Available on the Internet: https://www.youtube.com/watch?v=11D-kT9kZzk

[7] M. Kuruc, M. Zvončan, J. Peterka: Comparison of conventional milling and milling assisted by ultrasound of aluminum alloy AW 5083. In IN-TECH 2013 : Proceedings of International Conference on Innovative Technologies, Budapest, Hungary 10.-13.09.2013. Rijeka : Faculty of Engineering University of Rijeka, 2013, pp.177-180. ISBN 978-953-6326-88-4.

[8] M. Kuruc, M. Zvončan, J. Peterka: Investigation of ultrasonic assisted milling of aluminum alloy AlMg4.5Mn. In Annals of DAAAM and Proceedings of DAAAM Symposium: 24th DAAAM Zadar 2013-10-23/26. ISSN 23041382.

[9] M. Kuruc, J. Peterka: Rotary ultrasonic machining of poly-crystalline cubic boron nitride. In IDS 2014. International Doctoral Seminar 2014: Proceedings of the 9th International Doctoral Seminar (IDS 2014), Zielona Góra, Poland, May 19 -21, 2014. University of Zielona Góra, 2014, pp. 110-116. ISBN 978-80-8096-195-4.

[10] M. Kuruc, M. Necpal, J. Peterka: Machining of poly-crystalline cubic boron nitride by laser beam machining in terms of surface roughness. In Journal of Production Engineering. Vol. 17, No. 1 (2014), pp. 101-104. ISSN 18214932.

[11] M. Kuruc, J. Urminský, M. Necpal, L. Morovič, J. Peterka: Comparison of machining of poly-crystalline cubic boron nitride by rotary ultrasonic machining and laser beam machining in terms of shape geometry. In Strojírenská technologie - Plzeň 2015: 6. mezinárodní konference. Sborník příspěvků. 1. vyd. Plzeň : Západočeská univerzita v Plzni, 2015, p. 122-128. ISBN 978-80-261-0304-2.

[12] Ultrasonic 20 linear, [online], [cit. 2014-12-12], Available on the Internet: http://en.dmgmori.com/products/ultrasonic/ultrasonic-linear/ultrasonic-20-linear

[13] M. Beňo, M. Zvončan, M. Kováč, J. Peterka: Circular interpolation and positioning accuracy deviation measurement on five axis machine tools with different structures. In: Tehnicki Vjesnik - Technical Gazette. - ISSN 1330-3651. Vol. 20, No. 3 (2013), pp. 479-484.

[14] M. Zvončan, M. Kováč, E. Kucháriková, I. Buranský: Cutting fluid's pressure influence on surface quality in Rotary Ultrasonic Machining. In: TEAM 2011 : Proceedings of the 3rd International Scientific and Expert Conference with simultaneously organised 17th International Scientific Conference CO-MAT-TECH 2011, 19th -21st October 2011, Trnava Slovakia. Slavonski Brod: University of Applied Sciences of Slavonski Brod, 2011. ISBN 978-953-559704-9. pp. 39-42.

[15] PowerMILL. [online], [cit. 2015-02-14]. Available on the Internet: http://www.powermill.com/

[16] M. Zvončan, M. Kováč, M. Beňo: Machine tool's DMG Ultrasonic 20 linear simulation in powermill CAM software. In: CA systems in production planning. ISSN 1335-3799. Vol. 12, No 1 (2012), pp. 90-93.

[17] Jiaqian Qin, Norimasa Nishiyama, Hiroaki Ohfuji, Toru Shinmei, Li Lei, Duanwei He, Tetsuo Irifune. 2012. Polycrystalline $\gamma$-boron: As hard as polycrystalline cubic boron nitride. Japan, $13 \mathrm{pp}$. Available on the Internet: http://arxiv.org/ftp/arxiv/papers/1203/1203.1748.pdf

[18] Changsha 3 Better Ultra-hard Materials Co. [online], [cit. 2014-10-23]. Available on the Internet: http://3bdiamond.com/

[19] Nanodiamond \& Superhard Thin-films. [online], [cit. 2014-01-30] Available on the Internet: http://www.cityu.edu.hk/cosdaf/cbn_property.htm 